MARTA WIATR

ORCID 0000-0002-0805-6522

Akademia Pedagogiki Specjalnej im. Marii Grzegorzewskiej

$w$ Warszawie

\title{
RODZICE W EDUKACJI - MIĘDZY DYSKURSEM INSTRUMENTALNO-TECHNICZNYM A KRYTYCZNO-EMANCYPACYJNYM
}

\begin{abstract}
AвSTRACt. Wiatr Marta, Rodzice w edukacji - między dyskursem instrumentalno-technicznym a krytycznoemancypacyjnym [Parents in Education - Between Instrumental-Technical and Critical-Emancipatory Discourses]. Studia Edukacyjne nr 54, 2019, Poznań 2019, pp. 199-220. Adam Mickiewicz University Press. ISSN 1233-6688. DOI: 10.14746/se.2019.54.12
\end{abstract}

This article presents an analysis of discourses on the subject of parental involvement in school education of a child and aims to emphasize the complexity of the topic and the diversity of research positions, as well as further practical implications for the theoretical assumptions adopted.

Initial considerations present the terminology functioning in the context of the parent-school relationship. Concepts such as cooperation and partnership (familiar in Poland) have been juxtaposed with English-language concepts engagement and involvement, relating to the participation in the child's education and/or supporting a child during learning. While English-language terminology stresses the function of this involvement and participation, which is improving the child's school achievements, the concepts of cooperation and partnership, prevalent in Poland, emphasize the very essence of the relationship and its determinants.

In this work, these concepts are presented against the background of the dominant instrumental-technical discourse and a less-emerging but very important critical-emancipatory discourse. Looking at the issue from different sides and analyzing its multifaceted structure allows to broaden the knowledge about the "figure" of a parent who is now emerging in education as a participant in the space of family-school relations.

Key words: family-school cooperation, family-school partnership, parental involvement/engagement in child's education, instrumental-technical discourse, critical-emancipatory discourse

Rodzicielskie działania na rzecz edukacji dziecka są uważane za istotny czynnik wspierający jego postępy w szkole i ważną przesłankę różnicowa- 
nia szkolnych sukcesów ${ }^{1}$. Badania dowodzą, że rodzicielskie zaangażowanie przyczynia się do pozytywnych postaw uczniów wobec szkoły, poprawia samoocenę dzieci i wzmacnia ich motywację do nauki, pozytywnie wpływa na frekwencję, średnią ocen i wyniki w testach kontrolnych ${ }^{2}$. Ponadto, aktywność rodzicielska jest postrzegana jako istotny element rozwoju szkoły i nauczycieli ${ }^{3}$ oraz ma znaczenie w wymiarze pozaszkolnym - w postaci wzmacniania procesów demokracji, wzrostu odpowiedzialności, wyrównywania społecznych zasobów, czy rozwiązywania społecznych problemów związanych z dorastaniem młodzieży 4 . Wobec licznych korzyści (dydaktycznych, pedagogicznych, społecznych, administracyjnych, czy politycznych) związanych z włączaniem (się) rodziców w edukację dzieci, w wielu krajach od kilku dekad opracowywane są programy, strategie i modele zwiększające zaangażowanie rodziców w pracę szkoły. Uznanie wartości pracy rodziców na rzecz sukcesu szkolnego dzieci znajduje także odwzorowanie w polityce oświatowej i zmianach regulacji prawnych dokonywanych w ostatnich 30. latach w Europie ${ }^{5}$ oraz na świecie $^{6}$. Zabezpieczają one rodzicom miejsce i głos w przestrzeni szkolnej, wsuwając przysłowiową "stopę w drzwi” - opartej dotychczas wyłącznie na pracy profesjonalistów - szkolnej instytucji. Rozwiązania prawne (organy zarządzania szkołą i ich kompetencje, wymagania wobec szkoły i kryteria oceny szkoły)

${ }^{1}$ Np. F. Avvisati, B. Besbas, N. Guyon, Parental involvement in school: A literature review, Revue d'économie politique, 2010, 120; L. Boonk i in., A review of the relationship between parental involvement indicators and academic achievement, Educational Research Review, 2018, 24; C. Desforges, A. Abouchaar, The Impact of Parental Involvement, Parental Support and Family Education on Pupil Achievements and Adjustment: A Literature Review with, Education, 2003, 30, 8; X. Fan, M. Chen, Parental Involvement and Students' Academic Achievement: A Meta-Analysis, Educational Psychology Review, 2001, 13, 1; N.E. Hill, D.F. Tyson, Parental Involvement in Middle School: A Meta-Analytic Assessment of the Strategies That Promote Achievement, Developmental Psychology, 2009, 45, 3 .

${ }^{2}$ Np. M. Whitaker, K.V. Hoover-Dempsey, School Influences on Parents' Role Beliefs, The Elementary School Journal, 2013, 114, 1.

${ }^{3}$ Nauczyciele i rodzice: komunikacja, relacje, wspótpraca, red. J. Łukasiewicz-Wieleba, Warszawa 2014; M. Mendel, Partnerstwo rodziny szkoły i gminy, Torun 2000; M. Mendel, Pedagogika miejsca wspólnego. Miato i szkoła, Gdańsk 2018; L. Posey-Maddox, Professionalizing the PTO: Race, Class, and Shifting Norms of Parental Engagement in a City Public School, American Journal of Education, 2013, 119, 2.

${ }^{4}$ OECD, The Well-being of Nations. The Role of Human and Social Capital, OECD, Paris 2001; E. Theodorou, Reading between the lines: exploring the assumptions and implications of parental involvement, International Journal about Parents in Education, 2007, 1.

${ }^{5}$ Eurydice, Rola rodziców w systemach edukacyjnych Unii Europejskiej Informacji o Edukacji, EURYDICE, Bruksela 1997.

${ }^{6}$ Np. K. Brien, B.L. Stelmach, Legal and Cultural Contexts of Parent-Teacher Interactions: School Councils in Canada, International Journal about Parents in Education, 2009, 3, 1; G.L. Watson, R.E. Sanders-Lawson, L. McNeal, Understanding Parental Involvement in American Public Education Department of Leadership, International Journal of Humanities and Social Science, [Special Issue - October], 2012, 2, 19. 
i/lub infrastrukturalne (np. osobny pokój dla rodziców w szkole), choć same w sobie nie są dowodem partnerskiej współpracy między rodzicami i szkołą, i nie przesądzają o pojawieniu się rodzicielskiego zaangażowania, tworzą jednak okoliczności sprzyjające rodzicielskiej aktywności.

Mimo podzielanego entuzjazmu na temat korzyści płynących z dobrych relacji rodziny i szkoły oraz angażowania się rodziców w edukację dzieci, nauczyciele dostrzegają $\mathrm{w}$ budowaniu współpracy z rodzicami duże wyzwanie ${ }^{7}$. W literaturze przedmiotu sporo uwagi poświęca się tak zwanym działaniom pozorowanym, które jedynie $\mathrm{w}$ warstwie deklaracji ujawniają pro-partnerską postawę, niedostrzegalną $\mathrm{w}$ praktyce ${ }^{8}$. Wpływają na to różne czynniki, które przerabiają szczytne hasła na gruncie kultury oraz indywidualnych doświadczeń i interpretacji.

\section{Współdziałanie, współpraca, partnerstwo vs engagement i involvement}

Istnieje szereg różnych określeń, które odnoszą się do wachlarza działań podejmowanych przez rodziców na rzecz edukacji dziecka. W tradycji polskich badań koncentrują się one wokół relacji, jaka przy okazji tych działań rozwija się między rodziną i szkołą. Pojawiają się tu koncepcje współpracy, współdziałania i/lub partnerstwa rodziny. Choć istnieją stanowiska utożsamiające kategorie współdziałania i współpracy, stosując je wymiennie ${ }^{9}$, część autorów je rozróżnia ${ }^{10}$. Współdziałanie jest przez nich traktowane jako kategoria szersza od współpracy. Akcentuje się tu znaczenie wspierania, popierania, wzmacniania czyichś starań i wysiłków w osiągnięciu wyznaczonego celu. W relacji rodziców ze szkołą może ono przybierać postać wspierania działań szkoły ukierunkowanych na cel wyznaczony przez nauczycieli. Inicjatywa w przypadku współdziałania leży po stronie szkoły, rodzic zaś postrzegany jest jako pomocnik.

${ }^{7} \mathrm{~Np}$. A. Dor, Israeli teachers' attitudes toward parental involvement in school : A qualitative stu$d y$, International Journal about Parents in Education, 2013, 7, 1; B. Lulek, Wspótpraca szkoły, rodziny i środowiska, Rzeszów 2008; D. Markow, A. Pieters, The MetLife Survey of The American Teacher: Teachers, Parents and the Economy, New York 2012.

${ }^{8}$ M. Mendel, Miejsca rodziców w przestrzeni szkoty, [w:] Nauczyciele i rodzice, red. I. Nowosad, M.J. Szymański, Zielona Góra - Kraków 2004; K. Polak, Integracja rodziców i nauczycieli jako przykład edukacyjnej iluzji, [w:] Sprawcy i/lub ofiary działań pozornych w edukacji szkolnej, red. M. Dudzikowa, K. Knasiecka-Falbierska, Kraków 2013; B. Śliwerski, Meblowanie szkolnej demokracji, t. 2, Warszawa 2017.

${ }^{9}$ Np. M. Łobocki, Współdziałanie nauczycieli i rodziców w procesie wychowania, Warszawa 1985.

${ }^{10}$ Np. B. Lulek, Wspótpraca szkoty, rodziny i środowiska; L. Pietruszka, Rodzina i szkoła: O wspótpracy nauczycieli-wychowawców z rodzicami w procesie edukacji wczesnoszkolnej, Lublin 2017. 
Współpraca, utożsamiana przez niektórych z uczestnictwem, partycypacją rodziców w wychowaniu dzieci ${ }^{11}$, opiera się na wspólnie uzgodnionym celu i wyodrębnionych zadaniach cząstkowych ${ }^{12}$. Taka relacja wymaga nie tylko drożnych kanałów komunikacyjnych, o wprowadzaniu których instruuje bogata literatura poradnikowa, ale przede wszystkim równoważnej pozycji wszystkich stron. Współpraca wyklucza element dominacji.

Równoważność ta i zaangażowanie obu stron relacji podkreślana jest jeszcze wyraźniej w koncepcji partnerstwa, wprowadzonej do polskiej literatury przez Marię Mendel ${ }^{13}$. Partnerstwo to szczególna jakość współpracy. Jest relacją, która akcentuje wspólną odpowiedzialność za powodzenie starań i oparta jest na wzajemnym szacunku oraz uznaniu. Właśnie te jej cechy mają decydujący wpływ na siłę związku między rodziną i szkołą. Idee partnerstwa są rozwijane w koncepcji przymierza skupiającym się na silnym sojuszu rodziców i nauczycieli stojących po tej samej stronie - stronie ucznia ${ }^{14}$.

Choć badacze oraz teoretycy relacji rodziny i szkoły za pożądane formy uznają głównie partnerstwo i współpracę, w pracach naukowych wymienia się ponadto: przystosowanie (adaptację do szkolnych oczekiwań rodzicielskiej aktywności), inercję (bierność) i opozycję (opór czy wręcz konflikt) ${ }^{15}$. Wyróżnione formy Kawula i jego naśladowcy stopniują według przypisanej im wartości, gdzie współpraca (o cechach partnerstwa) jest tą najbardziej pożądaną.

W polskiej literaturze badacze skupiają się zatem na nazwaniu, opisie i analizie relacji rodziny oraz szkoły, przede wszystkim poprzez określenie i odwołanie się do jej pożądanej formy. W literaturze anglojęzycznej, choć również obecne są pojęcia charakteryzujące relację - czyli współpracę (cooperation) i partnerstwo (partnership) - często używa się kategorii związanych z działaniem (nierzadko wykraczającym poza samą relację rodzina-szkoła). Są to działania na rzecz edukacji dziecka (involvement) oraz zaangażowanie (się) (engagement). Tłumaczenia obu tych pojęć na polski nie są proste. $\mathrm{W}$ rzeczywistości obydwa oznaczają bowiem zaangażowanie/włączanie. Mendel proponuje tłumaczenie involvement jako zaangażowanie, zaś engagement jako "zaangażowanie publiczne" ${ }^{\prime 16}$. Ja pozostanę przy rozumieniu działań na rzecz edukacji dziecka pod pojęciem involvement oraz zaangażowania o znaczeniu "głębokiego uczestnictwa" pod pojęciem engagement. W wielu obcojęzycznych pracach pojęcia te stosowane są wymiennie lub używane jest wyłącz-

${ }^{11}$ Por. S. Kawula, Pedagogika społeczna. Dokonania, aktualność, perspektywy. Podręcznik akademicki dla pedagogów, Torun 2001.

12 B. Lulek, Wspótpraca szkoły, rodziny i środowiska.

${ }^{13}$ M. Mendel, Partnerstwo rodziny szkoty i gminy.

${ }_{14}$ M. Mendel, Rodzice i nauczyciele jako sprzymierzeńcy, Gdańsk 2007.

${ }^{15}$ S. Kawula, Pedagogika społeczna. Dokonania, aktualność, perspektywy.

${ }^{16}$ M. Mendel, Pedagogika miejsca wspólnego. Miasto i szkoła. 
nie pierwsze $\mathrm{z}$ nich ${ }^{17}$. Rozumie się przez nie przede wszystkim interakcje rodziców z nauczycielami w celu wspierania szkolnego sukcesu dzieci ${ }^{18}$, ale także rodzaj zaangażowania/ulokowania, zainwestowania zasobów i czasu w szkolnym wymiarze życia dzieci ${ }^{19}$.

Jednakże, nie dla wszystkich utożsamianie tych terminów jest uzasadnione. Istnieje liczna grupa badaczy, którzy odróżniają aktywność/aktywizowanie rodziców na rzecz edukacji dzieci poprzez różne programy szkolne (involvement) od zaangażowania rodziców rozumianego jako działanie wypływające z ich wewnętrznej motywacji do wspierania edukacji dziecka (engagement $)^{20}$. Jeynes odwołując się do badań, stwierdza, że szkolne programy aktywizowania rodziców (involvement) są skuteczne, ponieważ angażują w działania na rzecz edukacji dziecka rodziców nieaktywnych i przez to poprawiają wyniki szkolne uczniów. Jednakże, siła wpływu działań rodziców na sukcesy szkolne zależna jest, zdaniem badaczy, od tego, czy owo działanie płynie z głębokiej potrzeby i wewnętrznego przekonania rodziców, czy jest wywołane i rozbudzone przez zewnętrzne procedury szkolne. Obydwa te sposoby działania mają również rozleglejsze, niż wyniki szkolne, konsekwencje. Kalifornijski nauczyciel Larry Ferlazzo zauważa, że aktywizowanie rodziców (involvement) jest zjawiskiem inicjowanym przez nauczycieli i dlatego uwzględnia właśnie szkolne interesy, do których rodzice się dostosowują, zaś zaangażowanie (engagement), płynąc z wewnętrznej potrzebny rodziców, wymaga od samej szkoły uwzględnienia także ich celów, interesów i zasobów, a tym samym stawia uczestników relacji w innej roli²1. Aktywizowanie do działań na rzecz edukacji dziecka sprowadza się do stosowania procedur, które pozwalają rodzicom brać udział w tym co dzieje się w szkole 22 , przy czym zakres i kierunek działań rodzica jest regulowany przez szkołę. Rodzice

17 A. Dor, Israeli teachers' attitudes toward parental involvement in school; J.L. Epstein, S.B. Sheldon, Present and Accounted for: Improving Student Attendance Through Family and Community Involvement, The Journal of Educational Research, 2002, 95, 5; L. Posey-Maddox, A. Haley-Lock, One Size Does Not Fit All: Understanding Parent Engagement in the Contexts of Work, Family, and Public Schooling, Urban Education, 2016.

18 A. Dor, Israeli teachers' attitudes toward parental involvement in school; N.E. Hill, D.F. Tyson, Parental Involvement in Middle School.

${ }^{19}$ K.W. Murray i in., Barriers and Facilitators to School-Based Parent Involvement for Parents of Urban Public Middle School Students, SAge Open, 2014, 4, 4.

${ }^{20} \mathrm{~J}$. Goodall, C. Montgomery, Parental involvement to parental engagement: a continuum, Educational Review, 2014, 66, 4; W.H. Jeynes, A Meta-Analysis of the Efficacy of Different Types of Parental Involvement Programs for Urban Students, Urban Education, 2012, 47, 4; L. Symeou, Family/ school liaisons in Cyprus: an investigation of families' perspectives and needs, [w:] Building Bridges Between Home and School, red. F. Smit, H. Moerel, K. Van Der Wolf, P. Sleegers, Nijmegen - Amsterdam 2001.

${ }^{21}$ L. Ferlazzo, Parent Involvement or Parent Engagement, 2009 r. ttp://www.education.com/ reference/article/parent-involvement/

${ }^{22}$ L. Symeou, Family/school liaisons in Cyprus. 
stają się najczęściej obserwatorami wydarzeń, które szkoła dla nich organizuje (np. zebrania, konsultacje, festyny), wykonawcami rodzicielskich obowiązków lub wolontariuszami na rzecz szkoły ${ }^{23}$. Rodzice sprowadzani są tu do roli pomocników nauczycieli, a ich aktywność skupia się na podnoszeniu wyników szkolnych poszczególnych uczniów. Impulsem aktywizującym rodziców jest bowiem dobro i dobrostan ich dziecka oraz jego indywidualne osiągnięcia. Nadaje to, jak twierdzą niektórzy badacze, rodzicielskim działaniom charakter instrumentalny, gdzie współdziałanie ze szkołą „opłaca się" i ma przełożyć się na sukces edukacyjny dziecka ${ }^{24}$.

Na tym bazowym poziomie działań na rzecz dziecka w szkole (involvement) można dostrzec poprawę wyników dziecka, jednak trudno mówić o zaawansowanej partycypacji społecznej i związanych z nią procesach demokracji życia społecznego. Dopiero bowiem angażowanie (się) rodziców (engagement) wprowadza dwustronne rozpoznanie i uwzględnienie potrzeb, interesów i celów; wprowadza perspektywę wielu stron. Kształtuje to inną relację - relację prawdziwie partnerską - i jednocześnie aktywuje zaawansowaną partycypację podmiotów. Tacy zaangażowani (engaged) rodzice działają nie tylko na rzecz własnego dziecka, ale także na rzecz rozwoju szkoły i środowiska lokalnego, w którym żyją. Przy tym, rozwijają swoje kompetencje obywatelskie, ale też kompetencje obywatelskie danego środowiska. Wspólna odpowiedzialność za kształt szkoły i jej organizację wiąże się z upodmiotowieniem rodzica, z jego empowermentem i partycypacją w szkolnej społeczności, które mają znaczenie nie tylko w przestrzeni szkolnej, ale również w środowisku lokalnym.

Zaangażowanie rodziców (engagement) odwołuje się do głębokiego, uważnego zainteresowania edukacją dzieci i działania na jej rzecz, zakorzenionego w biografiach jednostkowych i rodzinnych, w środowisku lokalnym oraz szerszym kontekście społeczno-kulturowym ${ }^{25}$. Engagement jest zatem formą pożądaną, a involvement najbardziej podstawową.

Ze względu na sposoby i formy aktywizowania rodziców, działania na rzecz edukacji dziecka (involvement) można odnieść do kategorii współdziałania lub do formy współpracy, jaką jest adaptacja ${ }^{26}$. Obydwie kategorie zamykają się w obszarze relacji rodziny i szkoły, dotycząc działań inicjowanych i kontrolowanych przez szkołę, w których rodzice zyskują rolę pomocników nauczyciela. Zakłada się tu zmianę - dostosowanie - zachowań rodziców. Za-

23 Tamże.

${ }^{24}$ F. Avvisati, B. Besbas, N. Guyon, Parental involvement in school; J. Kołodziejczyk, B. Walczak, Rodzice w szkole. Ramy instytucjonalne i charakterystyka zaangażowania, Trzeci Sektor, $2014,3$.

${ }_{25}$ M. Mendel, Pedagogika miejsca wspólnego; E. Patacchini, E. Patacchini, Y. Zenou, Intergenerational Education Transmission: Neighborhood Quality and/or Parents' Involvement? Stokholm 2007; C.E. Sleeter, E. Soriano-Ayala, A.J. González-Jimenez, Community Funds of Knowledge and Immigrant Associations: An Exploration from Southern Spain, [w:] Roma inclusion - International and Greek experiences, red. S. Mitakidou, Thessaloniki 2015.

26 S. Kawula, Pedagogika społeczna. Dokonania, aktualność, perspektywy. 
angażowanie zaś, uwzględniając potrzeby, możliwości, zasoby i cele samych rodziców, otwiera przestrzeń do partnerstwa. Kategorie partnerstwa i zaangażowania wpisują się w myślenie o dynamicznym zmienianiu szkoły i środowiska życia całej szkolnej społeczności poprzez pełne szacunku wspólne działanie - na zasadzie uczestnictwa, partycypacji ${ }^{27}$. Zakłada się tu dogłębną przebudowę szkolnych i środowiskowych struktur, uwzględniając perspektywy różnych uczestników tych struktur.

Pojęcia wykorzystywane do opisu zjawisk związanych z uczestnictwem rodziców w edukacji dziecka tworzą rodzaj osnowy, na której rozbudowywana, przebudowywana i porządkowana jest wiedza na ten temat. Zależnie od sposobu rozumienia tych pojęć mogą powstawać różne rodzaje wiedzy, które następnie otwierają jedne, a zamykają inne sposoby praktycznego działania. Na przykład, odwołanie się do kategorii włączania (się) i/lub angażowania (się) kieruje uwagę w kierunku sprawców tego działania - rodziców i ich aktywności. Nauczyciele występują tu jako ci wspierający, lub nie, rodzicielską aktywność w szkole. Odwołanie do pojęć partnerstwa i współpracy przenosi uwagę na relację, a w drugiej kolejności dopiero na sprawców konkretnych czynności. Przy założeniu, że relacja partnerska pozwala rodzicom w pożądany sposób angażować się w edukację dziecka, to właśnie tworzenie warunków dla jej rozwoju jest najważniejszym zadaniem.

W krajowej i międzynarodowej literaturze przedmiotu można dostrzec dwa główne rodzaje wiedzy splecione $\mathrm{z}$ odmiennymi dyskursami relacji rodziny i szkoły. Są to: wiedza normatywna z dyskursem instrumentalno-technicznym oraz wiedza krytyczna z dyskursem emancypacyjnym. Dyskurs rozumiany jest tu jako zakotwiczone w pewnym kontekście społeczno-kulturowym użycie języka na jakiś temat (np. relacji rodziny i szkoły), które generuje wiedzę, a zarazem udostępnia ją i kształtuje społeczne praktyki, wytwarzając w ten sposób społeczną rzeczywistość. Innymi słowy, język jest zakotwiczony $\mathrm{w}$ symbolicznych ramach społecznego porządku, który sam wytwarza, odtwarza, przetwarza. Zaproponowany podział na dwa dyskursy jest w swej naturze umowny, a granice poszczególnych dyskursów mogą się na siebie nakładać i ze sobą przenikać.

\section{Wiedza normatywna i dyskurs instrumentalno-techniczny}

W literaturze przedmiotu dominuje wiedza o charakterze normatywnym. Opiera się ona na dwóch istotnych przesłankach. Pierwsza, zakorzeniona $\mathrm{w}$ pozytywistycznym paradygmacie, widzi kategorie współpracy,

${ }^{27}$ B. Śliwerski, Możliwości rozpoznawania sensu współdziałania szkoły, rodziców i uczniów w spoteczeństwie wolnorynkowym, [w:] Nauczyciele i rodzice; L. Symeou, Family/school liaisons in Cyprus. 
partnerstwa, zaangażowania (się) i włączenia (się) jako byty wyodrębnione, obiektywne, uniwersalne, zewnętrzne i gotowe do pomiaru i interwencji. Nie dostrzega się tu społecznego konstruowania współpracy, partnerstwa, czy zaangażowania. Zamiast tego wymienione kategorie jawią się jako realnie istniejące obiekty. Są one traktowane jako mierzalne, a wiedza pochodząca z tych pomiarów, jako możliwa do zastosowania, funkcjonuje niezależnie od społeczno-kulturowego kontekstu.

Druga przesłanka wiąże się z powinnościowym charakterem omawianych pojęć. Zarówno w polskiej, jak i międzynarodowej literaturze o relacji i sposobie działania rodziców mówi się w odniesieniu do ich pożądanego kształtu. Pomija się fakt, że kategorie te są raczej społecznymi konstruktami, ideami, postulatami, niż realnymi bytami. Naukowcy usiłują zatem uchwycić i sprecyzować kształt tego co być powinno i dopiero w drugiej kolejności odnoszą się to do tego co jest i jak jest? Wyraźny rozdźwięk między tym jak być powinno a jak jest znajduje różne wyjaśnienia. Często te dwa aspekty, zamiast do sfery społecznych znaczeń i konstrukcji, sięgają do indywidualnych atrybucji, osadzając zjawisko w sferze jednostkowych, moralnych wyborów.

Odbiciem tego pozytywistycznego nurtu $\mathrm{w}$ badaniach nad relacją rodziny i szkoły są liczne ilościowe badania zorientowane na uchwycenie zakresu zjawiska, charakteru zaangażowania rodziców w edukację dzieci, form, w jakich ona występuje. Badacze i badaczki zmierzają do możliwie najwnikliwszego rozpoznania owego wydzielonego "obiektu”, do jego precyzyjnej definicji, ustalenia jego zakresów, do uchwycenia jego składowych elementów, a także charakteru czy uwarunkowań. Jest to teren dobrze rozpoznany i opisany. Wśród polskich badaczy wymienić należy na przykład Łobockiego ${ }^{28}$, Winiarskiego ${ }^{29}$, Kawulę i Jankego ${ }^{30}$, Lulek ${ }^{31}$, czy Szymańskie$\mathrm{go}^{32}$. Oprócz badaczy i badaczek skoncentrowanych na badaniu relacji rodziny i szkoły pojawiają się liczne artykuły autorów, którzy jednorazowo wypowiadają się na te tematy.

W obcojęzycznej literaturze wśród prac zmierzających do operacjonalizacji rodzicielskiego zaangażowania i do jego pomiarów wyróżnia się przede

${ }^{28}$ M. Łobocki, Wspótdziałanie nauczycieli i rodziców w procesie wychowania; tenże, O wspótpracy nauczycieli i rodziców w rozumieniu tradycyjnym, [w:] Nauczyciele i rodzice.

${ }^{29}$ M. Winiarski, Rodzina, szkoła, środowisko lokalne: Problemy edukacji środowiskowej, Warszawa 2000.

${ }^{30}$ S. Kawula, J. Brągiel, A.W. Janke, Pedagogika rodziny, Torun 1998.

${ }^{31}$ B. Lulek, Wspótpraca szkoty, rodziny i środowiska; tenże, Rodzice jako liderzy w edukacji szkolnej własnego dziecka. O trudnościach w budowaniu rodzicelskich zespołów w szkole, [w:] Education and upbringing in the educational school system, red. K. Denek, A. Kamińska, P. Oleśniewicz, Sosnowiec 2013.

${ }^{32}$ M.J. Szymański, Rodzina i szkoła w procesie gwattownej zmiany społecznej, [w:] Nauczyciele i rodzice; tenże, Rodzina i szkoła - wspólnota dążeń czy interesów? [w:] Rodzina i szkoła: od rozpoznania problemów do efektywnej wspótpracy, red. M. Jaśko, J. Siewiora, Tarnów 2017. 
wszystkim prace Epstein, Dauber, Daviesa, Hoover-Dempsey, Sandlera, Sheldona $^{33}$. Owi badacze i badaczki proponują oraz rozwijają dwa wielowymiarowe modele rodzicielskiej aktywności (involvement) na rzecz edukacji dzieci. W anglojęzycznej literaturze liczne badania różnych elementów, zakresów i wymiarów rodzicielskiej aktywności na rzecz szkoły co kilka lat poddawane są metaanalizom, które ujawniają ważniejsze trendy i aktualne ustalenia dotyczące tego, jakie działania i w jakim stopniu wpływają na uczniowskie osiągnięcia $^{34}$.

Do korpusu wiedzy normatywnej zaliczają się rozmaite katalogi i typologie porządkujące wiedzę na temat relacji rodziny i szkoły. Badacze tworzą zestawienia różnych działań, które zaliczane są do przejawów współpracy szkolno-rodzinnej. Wymienia się takie aktywności, jak: pomoc w lekcjach, udział w zebraniach, korzystanie z konsultacji indywidualnych, inne formy komunikacji zdalnej, świadczenie prac na rzecz szkoły - wolontariat, pomoc w szkolnych imprezach, zasiadanie w szkolnych organach i w ich ramach, opiniowanie planowanych i podejmowanych przez szkołę działań oraz współdecydowanie w sprawie różnych szkolnych działań. W anglojęzycznej literaturze różne formy aktywności na rzecz edukacji dzieci dzieli się na te realizowane w szkole (school-based) i w domu (home-based). Polscy badacze z kolei dzielą formy aktywności rodziców na ogólniejsze kategorie działań indywidualnych i grupowych, lub bezpośrednich i zdalnych. Różnego rodzaju katalogi mają przede wszystkim walor opisowo-porządkujący.

Dociekania badaczy zorientowane są na uchwycenie uwarunkowań i ewentualnych przeszkód, które uniemożliwiają rozkwit pożądanej formy współpracy. Stawiają pytania o to, w jaki sposób postrzegają się wzajemnie nauczyciele i rodzice, czego od siebie oczekują, w jaki sposób rodzice i nauczyciele oceniają gotowość szkoły do partnerstwa w szkole, przygotowanie do włączania rodziców do aktywności na rzecz edukacji dziecka, rozpoznanie strony aktywnej w inicjowaniu kontaktu i kontrolowania współpracy ${ }^{35}$.

${ }_{33}$ Crossing Boundaries: Multi-National Action Research on Family-School Collaboration. Report No. 33., red. D. Davies, V. Johnson, Baltimore 1996; J.L. Epstein, S.L. Dauber, Teacher attitudes and practices of parent involvement in inner-city elementary and middle schools. Report No. 32, [w:] Research On Elementary \& Middle Schools. Report No. 32, 1989; J.L. Epstein, S.B. Sheldon, Present and Accounted for: Improving Student Attendance Through Family; J.M.T. Walker i in., Parental Involvement: Model Revision through Scale Development, The Elementary School Journal, 2005, 106, 2.

34 F. Avvisati, B. Besbas, N. Guyon, Parental involvement in school; L. Boonk i in., A review of the relationship between parental; C. Desforges, A. Abouchaar, The Impact of Parental Involvement; N.E. Hill, D.F. Tyson, Parental Involvement in Middle School.

35 J.L. Epstein, Improving Family and Community Involvement in Secondary Schools DATA, The Education Digest, 2008, February; J. Kołodziejczyk, H. Cieślak, Analiza wyników ewaluacji zewnętrznych w odniesieniu do wymaganiań. "Rodzice sa partnerami szkoty”, [w:] Ewaluacja w nadzorze pedagogicznym, red. G. Mazurkiewicz, Kraków 2011; J. Kołodziejczyk, B. Walczak, T. Kasprzak, Rodzice - Partnerzy szkoły?Perspektywa ewaluacyjna, Polityka Społeczna, 2012, 1; J. Łukasiewicz- 
Jeden z ważniejszych i silniejszych nurtów badań nad współpracą i jej barierami rozwija się wokół, wspomnianej w pierwszej części artykułu, typologii rodzicielskiego uczestnictwa $\mathrm{w}$ edukacji ${ }^{36}$. Wyróżnia ona różne poziomy zaangażowania rodziców w sprawy szkolne dzieci - od partnerskiej współpracy przez adaptację, bierność, po opór. Podział ten znajduje zastosowanie u wielu badaczy w tworzeniu typologii rodziców. Pojawiają się zatem rodzice współpracujący - partnerzy, rodzice adaptujący się, rodzice bierni i rodzice konfliktowi (często określani mianem roszczeniowych). Ale nie są to jedyne podziały rodzicielskiej populacji. Mówi się o rodzicach współpracujących, nadopiekuńczych, trzymających dzieci pod kloszem ${ }^{37}$. Charakterystyczną cechą tego rodzaju wiedzy jest owa indywidualna lub grupowa atrybucja pewnej cechy, która zdaniem autorów jest odpowiedzialna za niepowodzenie współpracy. Na przykład, bierność rodziców lub ich nadmierny lęk o dziecko stanowi przeszkodę na drodze urzeczywistnienia partnerstwa szkoły i rodziny. Olubiński właśnie rodziców wini za brak realizacji szczytnego celu. Jego zdaniem, rodzice są niedouczeni, nieświadomi, „,mierni i bierni"38. Rodzice partnerscy współpracujący ze szkołą są cenieni i chwaleni, a ci „bierni” i „oporni” piętnowani. Przeniesienie punktu ciężkości z charakteru relacji na samego rodzica pozwala zindywidualizować przyczyny niepowodzeń w realizacji współpracy rodziny i szkoły. Rodzic staje się celem interwencji mających uczynić go bardziej aktywnym i bardziej zaangażowanym w sprawy edukacyjne. Pojawiają się propozycje pedagogizacji, a więc uświadamiania rodzicom własnej roli i uczenia pożądanych zachowań, a co za tym idzie - przekształcenia ich w odpowiednich pomocników nauczyciela. Mimo że najczęściej niepowodzenia związane są z określonymi typami rodziców ${ }^{39}$, w literaturze można znaleźć także negatywne typy nauczycieli, jak na przykład nauczyciel uległy lub kontrolujący ${ }^{40}$.

-Wieleba (red.), Nauczyciele i rodzice : komunikacja, relacje, wspótpraca; B. Lulek, Wspótpraca szkoty, rodziny i środowiska; K.W. Murray i in., Barriers and Facilitators to School-Based Parent Involvement; I. Nowosad, W poszukiwaniu warunków wspótpracy nauczycieli i rodziców, [w:] Nauczyciele i rodzice; W. Segiet, Psychospołeczna charakterystyka stosunków rodzice-nauczyciele, [w:] Tamże; taże, O zwiazku edukacji z rodzina: Społeczne konteksty i jednostkowe biografie, Poznań 2013; J.M.T. Walker i in., Parental Involvement: Model Revision through Scale Development; J.M.T. Walker i in., Parental Involvement in Homework. A Review of Current Research and Its Implications for Teachers, After School Program Staff, and Parent Leaders, Cambridge 2004.

${ }^{36}$ S. Kawula, Pedagogika społeczna. Dokonania, aktualność, perspektywy.

${ }^{37}$ M. Goetz, Chowane pod kloszem, Głos Nauczycielski, 2016, 27-28; B. Lulek, Rodzice jako liderzy w edukacji szkolnej własnego dziecka; L. Pietruszka, Rodzina i szkoła: O wspótpracy.

38 A. Olubiński, Wspótpraca rodziny i szkoty jako funkcja życia społecznego, [w:] Wspótprzestrzenie edukacji, red. M. Nyczaj-Drąg, M. Głażewski, Kraków 2005.

${ }^{39}$ J. Łukasik, K. Jagielska, R. Solecki, Nauczyciel. Wychowawca. Pedagog. Szkolne wyzwania, Kielce 2013; B. Lulek, Rodzice jako liderzy w edukacji szkolnej własnego dziecka; L. Pietruszka, Rodzina i szkoła: O wspótpracy nauczycieli-wychowawców.

${ }^{40}$ J. Łukasik, K. Jagielska, R. Solecki, Nauczyciel. Wychowawca. Pedagog. 
Nagromadzona wiedza o charakterze normatywnym staje się dobrym gruntem dla dyskursu instrumentalno-technicznego. Czerpie on z niej cele i koncentruje się na efektywnych sposobach ich osiągania. Sprzyja rozwiązaniom o charakterze technicznym, dostarcza wiedzy o tym, jak działać skutecznie. Mniej istotne jest w jego ramach pytanie o zasadność czy problematyczność owego celu, czy o jego pogłębione uzasadnienie ${ }^{41}$. W literaturze przedmiotu dyskurs ten jest wyraźnie zdominowany przez język psychologii i zarządzania. To akurat nie dziwi, biorąc pod uwagę normatywną indywidualizację i psychologizację problemów oraz niepowodzeń doświadczanych $\mathrm{w}$ projektowanej relacji rodzice i nauczyciele. Zadaniem stojącym przed nauczycielem jako tym, który inicjuje i kontroluje współpracę z rodzicami, jest odpowiednie zdiagnozowanie rodzica jako "partnera" relacji oraz zaszeregowanie go do właściwego typu. Na tej podstawie można, sięgając do poradników, kierować do poszczególnych kategorii odpowiednio opracowane działania. Tu korzysta się z różnych narzędzi komunikacyjnych, emocjonalnych, czy poznawczych będących sposobem na uporanie się z niskim poziomem współpracy w szkole czy niskim poziomem zaangażowania rodzicielskiego w edukację dziecka. Platformą wymiany i przekazywania tego rodzaju wiedzy są poradniki krajowe ${ }^{42}$ i zagraniczne ${ }^{43}$ oraz pisma kierowane do praktyków, jak na przykład "Nowa Szkoła”, „Dyrektor Szkoły”, „Wychowawca”, "Głos Nauczycielski" i tym podobne. To ostatnie w 2016 roku prowadziło cykl artykułów zatytułowanych Rodzice w szkole. Obok tekstów dedykowanych profesjonalistom istnieje także zbiór opracowań o charakterze stricte naukowym, badawczym, które w zależności od rodzaju, poza prezentacją badań i ich wyników lub poza charakterystyką wybranych elementów relacji rodziców ze szkołą, przedstawiają także propozycje rozwiązań w tym zakre$\operatorname{sie}^{44}$. Cel, jaki stanowi współpraca rodziny i szkoły przyjmowany jest bezkrytycznie, a wszyscy uczestnicy relacji traktowani jako homogeniczne kategorie nauczycieli i rodziców. W tym podejściu jedyną problematyczną kwestią pozostaje, zdawać by się mogło, "pozyskanie rodzica” dla owego celu. Rodzic nie jest bowiem zapraszany do negocjacji celu czy jego sformułowania, ale do przyjęcia, jakże niejasnego celu - współpracy ze szkołą. Zalecenia płynące $\mathrm{z}$ takich prac niezmiennie dotyczą korekty zachowania (jednej lub drugiej strony) w relacji z rodzicem - a więc rozwijania wzajemnej empatii, budowania zaufania, uczenia się aktywnego słuchania, umiejętności identyfikowania

${ }^{41}$ R. Kwaśnica, Dyskurs edukacyjny po inwazji rozumu instrumentalnego. O potrzebie refleksyjności, Wrocław 2014.

42 I. Dzierzgowska, Rodzice w szkole: [poradnik dla dyrektorów szkót, nauczycieli i rodziców], Warszawa 2001; A. Jankowska, Rozmowy z rodzicami: Poradnik dla nauczyciela, Kielce 2012.

${ }^{43}$ C.J. Christopher, Nauczyciel-rodzic: Skuteczne porozumiewanie się, Gdańsk 2009; M. Whalley, Jak włączyć rodziców do nauki dzieci, Warszawa 2008.

${ }^{44}$ Por. L. Pietruszka, Rodzina i szkoła: O wspótpracy nauczycieli-wychowawców. 
i rozwiązywania konfliktów, organizowania współpracy i administrowania współpracą (arkusze, ankiety, formularze), a także interpretacji prawa oświatowego oraz doradztwa prawnego w budowaniu współpracy.

W tym dominującym dyskursie normatywnym brak współpracy ze szkołą lub brak rodzicielskiego zaangażowania w formie oczekiwanej przez szkolną instytucję jest interpretowany w kategoriach nieodpowiedniego wyposażenia kulturowego środowiska rodzinnego, indywidualnych patologii i deficytów rodziny lub braku chęci i niezrozumienia zadania. W tym nurcie wiedzy, ale gdzieś na jej obrzeżach, pojawiają się również prace krytyczne wobec indywidualnych atrybucji, dostrzegające szerszy psychospołeczny kontekst zjawiska współpracy rodziców i nauczycieli. Wskazuje się w nich także pozarodzinne przyczyny niepowodzeń w nawiązywaniu pozytywnej relacji rodziny i szkoły. Dostrzegane są czynniki społeczno-psychologiczne oraz społeczno-polityczne w budowaniu wsparcia rodziny i szkoły dla uczącego się dziecka ${ }^{45}$. Na przykład, Mendel trudności w budowaniu relacji partnerskiej upatruje nie $\mathrm{w}$ indywidualnych charakterystykach czy woli poszczególnych podmiotów relacji, ale $\mathrm{w}$ strukturalno-instytucjonalnym kontekście wprowadzającym różnice statusu między rodzicami i nauczycielami. Różnice te stoją na przeszkodzie autentycznego procesu wspólnej pracy, o przymierzu nie wspominając. Autorka zwraca uwagę na symboliczne przejawy nierównych statusów nauczycieli i rodziców w szkole, to jest na przykład brak miejsc dla rodziców w szkole, czy forsowanie koncepcji pedagogizacji rodziców. Według Mendel, to właśnie rodzice uznani są za tych, którzy zanim wkroczą w relację partnerską, muszą zostać odpowiednio skorygowani w procesie pedagogizacji. Rodzic tym samym jest traktowany jako partner bez zasobów.

Konieczna prezentuje trudności komunikacyjne w rozmowach rodziców $\mathrm{z}$ nauczycielami, zakorzenione $\mathrm{w}$ dyskursywnych ramach szkolnej instytucji funkcjonującej w szerszym kontekście systemu oświaty (ustalonych standardach ucznia, uczenia się oraz w praktykach oceniania pracy nauczyciela). Śliwerski ujawnia zaś sprzeczne tendencje w obszarze prawno-administracyjnych rozwiązań, które deklaratywnie mają prowadzić do uspołecznienia szkoły i rodzicielskiej partycypacji.

Krytyczny charakter tych prac kwestionuje stricte psychologiczno-wolicjonalne przyczyny niepowodzeń partnerstwa i zaangażowania, jednak nie

${ }^{45}$ A. Konieczna, Analiza struktury interakcji w sytuacji rozmowy nauczycieli z rodzicami o problemach szkolnych ucznia, Warszawa 2009; M. Mendel, Miejsca rodziców w przestrzeni szkoły; taże, Aktywna szkoła - bierni rodzice: anomia, mit czy przemieszczenie znaczeń? [w:] Pedagogika rodziny na progu XXI wieku, red. A. W. Janke, Toruń 2004; W. Segiet, Psychospołeczna charakterystyka stosunków rodzice-nauczyciele; B. Śliwerski, Uspołecznienie szkoły, Edukacja i Dialog, 1995, http:/ /edukacjaidialog.pl/archiwum/1995,93/styczen,105/uspolecznienie_szkoly,332.html\%0AKażdy; tenże, Klinika szkolnej demokracji, Kraków 2008. 
dotyka ram dyskursów i granic światów społecznych, w których różni rodzice i różni nauczyciele czynią swoje życie sensowne. Te bazowe refleksje nad znaczeniem pojęcia wspótpraca, wypracowane w obszarze wiedzy normatywnej i dyskursie instrumentalno-technicznym, stwarzają pole do pogłębiania i ukontekstowienia refleksji oraz badań nad koncepcją. Jednakże, potencjał ten nie jest wykorzystywany. Rzadko pojawiają się pytania o warunki rodzicielskiego bycia w szkole zachowujące równorzędność. Pomimo szerszej, psychospołecznej i instytucjonalnej perspektywy, którą wprowadzają wymienieni autorzy, dyskurs techniczno-instrumentalny i tu potrafi znaleźć swoją pożywkę. Mechaniczne stosowanie procedur w ramach różnych modeli i programów aktywizowania rodziców uczniów jest odpowiedzią właśnie $\mathrm{w}$ obrębie tego dyskursu. Wprawdzie proponowane programy pozwalają przezwyciężać bariery, o których między innymi wspominają także polscy autorzy, i pozwalać rodzicom brać udział w tym, co dzieje się w szkole ${ }^{46}$, jednak ta wiedza nie prowadzi do zakwestionowania zasadności takiej a nie innej koncepcji współpracy, partnerstwa, czy uczestnictwa. Nie prowadzi też do budowania rodzicielskiego zaangażowania ponad prostymi mechanizmami troski o własne dziecko, ku głębokim strukturom sensów dostępnych w lokalnym środowisku, sąsiedztwie, grupie etnicznej, rodzinie, czy własnej biografii. Bez zakwestionowania oczywistości i totalności samej koncepcji współpracy, działania na rzecz (involvement) czy zaangażowania, partycypacji (engagement) rozważania badaczy pozostają w normatywnej ramie zobowiązania do uniwersalnych działań

\section{W stronę wiedzy praktyczno-moralnej i dyskursu krytyczno-emancypacyjnego}

Wiedza normatywna totalizuje i naturalizuje rodzicielskie zaangażowanie. Rozwijana w jej ramach koncepcja współpracy angażuje wszystkich nauczycieli i rodziców traktowanych jako dwie wewnętrznie homogeniczne kategorie podmiotów. Nierówności statusowe rodziców są sprowadzone do społeczno-psychologicznych i wolicjonalnych trudności (bierni rodzice), możliwych do usunięcia dzięki poprawnej komunikacji i pracy nad postawami. Ta uniwersalizacja i totalizacja współpracy, pozbawiona krytycznej refleksji nad kulturowym i społecznym tłem zróżnicowania obu grup, staje się narzędziem dyscyplinowania populacji rodziców i/lub nauczycieli ${ }^{47}$. Rodzice aktywni, przedsiębiorczy, partnerscy wobec szkoły zasługują na miano

${ }^{46}$ L. Symeou, Family/school liaisons in Cyprus.

${ }^{47}$ M. Van den Berg, 'Activating' those that 'lag behind': space-time politics in Dutch parenting training for migrants, Patterns of Prejudice, 2016, 50, 1. 
dobrych. „Bierni” to ci, którym się nie udało, którzy nie mają woli (indywidulane przypisania), wiedzy i/lub poszanowania edukacyjnych wartości, by odpowiednio wspierać własne dzieci. W tym sensie uniwersalizacja i naturalizacja, jako modus operandi jednostki, w postaci zdefiniowanego rodzicielskiego zaangażowania i aktywności proszkolnej, nadają rodzicielstwu wymiar moralny i przenikają głęboko do procesów tożsamościowych. Nagradzani są ci, którzy dobrze odnajdują się w normach współpracy i partnerstwa, a piętnowani ci, którzy nie odczytują "reguł gry”. Jak zauważają przedstawiciele dyskursu krytycznego, środowisko staje się opresyjne dla tych rodziców, dla których szkolny kontekst jest obcy kulturowo i przez to niezrozumiały, niedostępny $^{48}$. Psychologizacja oraz indywidualizacja przyczyn niepowodzenia partnerstwa rodziny i szkoły prowadzi do przemilczenia faktu, że szkoła jest miejscem przemocy symbolicznej, która dotyka nie tylko uczniów, ale także ich rodziców oraz całe sąsiedztwa czy środowiska lokalne, jeśli nie dysponują one kapitałem niezbędnym do prowadzenia "szkolnych rozgrywek” w systemie oświaty. Te zależności i konteksty dostrzegają badacze krytyczni. W analizie uczestnictwa rodziców w edukacji punktem wyjścia czynią nie jednostkę, ale właśnie szkołę jako produkt pewnej kultury, który wyraża/ uwzględnia potrzeby, interesy i zasoby pewnych tylko grup społecznych. Taka perspektywa prowokuje badaczy do zadawania pytań o społeczno-kulturowe ramy konstruowania różnych pozycji rodziców z różnych lokalizacji struktury społecznej. Przyjęta przez niektórych autorów krytyczna perspektywa staje się podłożem dyskursu krytyczno-emancypacyjnego.

Dyskurs krytyczno-emancypacyjny jest bardzo słabo wykształcony w polskiej literaturze przedmiotu. Podejmuje go Mendel $^{49}$, wskazując na fasadowość wyizolowanych koncepcji współpracy oraz partnerstwa rodziny, szkoły i gminy. Dostrzega ona brak równowagi sił w definiowaniu owego partnerstwa oraz oferuje koncepcję wiążącą zarazem rodzicielskie działanie na rzecz edukacji dziecka (parent involvment), „zaangażowania społeczności” (community involvement) oraz "zaangażowania publicznego" (engagament). Wskazuje na polityczność tego rodzaju działań w przestrzeni społecznej, służących rozwojowi szkoły publicznej.

Na Zachodzie dyskurs krytyczno-emancypacyjny rozwija się dynamicznie od kilku dekad. Stawiane są tutaj pytania o kontekst (polityczny, ekonomiczny, kulturowy i społeczny) imperatywu rodzicielskiego zaangażowania oraz o jego społeczno-polityczne konsekwencje. Można w nim wyróżnić

48 A.P. Bohn, C.E. Sleeter, Multicultural education and the standards movement: A report from the field, Phi Delta Kappan, 2000, 82, 2; W.D. Hawley, S. Nieto, Another Inconvenient Truth: Race and Ethnicity Matter, Educational Leadership, 2010, 68, 3; C.E. Sleeter, E. Soriano-Ayala, A.J. González-Jimenez, Community Funds of Knowledge and Immigrant Associations.

${ }^{49}$ M. Mendel, Pedagogika miejsca wspólnego. Miato i szkoła. 
dwa poziomy rozważań dotyczących zróżnicowania statusów w relacji rodziców i nauczycieli. Na pierwszym z nich konieczne jest uwzględnienie kulturowo-instytucjonalnych ram, w obrębie których wytwarzane są te statusy. Chodziłoby zatem o strukturalne warunki tej relacji. Stanowią one ramy wyznaczające pole określonych działań możliwych do podjęcia przez rodziców i nauczycieli w warunkach danej historyczno-kulturowej instytucji szkolnej. Drugi poziom jest tłem dla pojęcia szkoły jako wytworu, produktu pewnych grup społecznych i przez to narzędzia ochrony oraz realizacji ich interesów ${ }^{50}$. Dla tych grup szkoła jest czytelna i przewidywalna, a jej oczekiwania zrozumiałe, także w kontekście partnerskiej współpracy rodziców i nauczycieli ujętej w obszarze wiedzy normatywnej ${ }^{51}$. Badacze nawiązują tu do kategorii kapitałów: społecznego, ekonomicznego, kulturowego i symbolicznego, jako istotnych, choć niebezpośrednich uwarunkowań pewnej wizji współpracy. Autorzy zauważają, że rodzice klasy średniej, z racji swojego kapitałowego wyposażenia korespondującego ze szkolnymi wymaganiami, zdają się bardzo dobrze w nią wpisywać. Z kolei rodzice z grup społecznych o niższych kapitałach lub ich niedoborach czują się obco w szkole i zdają się z nią nie współdziałać. Dla rodziców z grup nieuprzywilejowanych szkoła znajduje się poza światem ich doświadczenia $i$ jest instytucją niezrozumiałą oraz nieprzejrzystą ${ }^{52}$. W pracach traktujących na ten temat badacze rozprawiają się $\mathrm{z}$ bezkrytycznie przyjmowaną $\mathrm{w}$ nurcie normatywnym diagnozą bierności rodziców. Zmieniają perspektywę $\mathrm{z}$ tej indywidualistycznej na strukturalną, przenosząc ciężar oceny z jed-

${ }^{50}$ P. Bourdieu, J.-C. Passeron, Reprodukcja: Elementy teorii systemu nauczania, Warszawa 2012.

${ }^{51}$ S.J. Ball, R. Bowe, S. Gewirtz, School choice, social class and distinction: the realization of social advantage in education, Journal of Education Policy, 1996, 11, 1; G. Crozier, Parental involvement: Who wants it? International Studies in Sociology of Education, 1999, 9, 3; tenże, Excluded Parents: The deracialisation of parental involvement [1], Race Ethnicity and Education, 2001, 4, 4; G. Crozier, D. Reay, D. James, Making it work for their children: White middle-class parents and working-class schools, International Studies in Sociology of Education, 2011, 21, 3; A. Lareau, E.M. Horvat, Moments of Social Inclusion and Exclusion Race, Class, and Cultural Capital in Family-School Relationships, Sociology of Education, 1999, 72, 1; D. Reay, Unequal Childhoods: Class, Race and Family Life by Annette Lareau:Unequal Childhoods: Class, Race and Family Life, 2003, 1989; D. Reay, S.J. Ball, 'Making their Minds Up': family dynamics of school choice, British Educational Research Journal, 1998, 24, 4; C. Vincent, J. Martin, Class, Culture and Agency : researching parental voice, Discourse : Studies in the Cultural Politics of Education, 2002, 23, 1; C. Vincent i in., Being strategic, being watchful, being determined: Black middle-class parents and schooling., British Journal of Sociology of Education, 2012, 33, 3.

${ }^{52}$ P. Bourdieu, J.D. Waquant Loic, An Invitation to Reflexive Sociology, Chicago 1992; G. Crozier, Excluded Parents: The deracialisation of parental involvement [1]; E.M. Horvat, The Interactive Effects of Race and Class in Educational Research: Theoretical Insights from the Work of Pierre Bourdieu, 2003, 2, 1; A. Lareau, E.M. Horvat, Moments of Social Inclusion and Exclusion Race, Class, and Cultural Capital in Family-School. 
nostki na instytucję szkoły. Zdaniem Gill Crozier i Jane Davies ${ }^{53}$, zamiast mówić o trudnych we współpracy rodzicach (hard to reach parents), powinniśmy mówić o trudnych we współpracy szkołach (hard to reach schools). W publikacjach naukowych wskazywane są mechanizmy dyscyplinowania rodziców, które poprzez kategorie uniwersalizowania i normatywności aktywności na rzecz dziecka oraz zaangażowania w jego edukację wykluczają dużą część rodziców z kategorii rodziców zaangażowanych.

Zaangażowany rodzic mieści się w szerszej ramie neoliberalnego „obywatela" ${ }^{54}$ - jednostki aktywnej, przedsiębiorczej, zaangażowanej i odpowiedzialnej za dokonywane wybory, mającej łatwość w inicjowaniu partnerstw z innymi jednostkami, grupami lub instytucjami. Jak zauważają badacze, racjonalność, refleksyjność i uczestnictwo neoliberalnego obywatela jest jednak czytelna i dostępna wyłącznie dla przedstawicieli grup uprzywilejowanych. Już sam ten fakt dzieli populację - także rodziców - na spełniających wymogi neoliberalnego świata i tych, którzy im sprostać nie mogą. Owo wartościowanie ludzkich bytów według neoliberalnej miary należy do nowych technik zarządzania ludźmi. Ta kulturowo fundowana niemoc, sprowadzana do indywidualnych decyzji i wyborów, podlega współczesnym technikom zarządzania populacją poprzez wolność, w tym indywidualną wolność wyborów. Położenie nacisku na wolność, autonomię i wolną wolę jednostki zaciera istotne strukturalne konteksty, takie jak lokalizacja w strukturze społecznej oraz różnie dystrybuowane w populacji kapitały kulturowe, społeczne i ekonomiczne.

W dyskursie krytyczno-emancypacyjnym pojawiają się także prace podnoszące kwestie procesów demokratyzacji i empowermentu rzekomo wzmacnianych przez wspieranie rodzicielskiej partycypacji w życiu społeczności szkolnej. Stelmach i $\operatorname{Brian}^{55}$ zauważają, że entuzjazm związany z tymi procesami jest nieuzasadniony. Zgodnie $\mathrm{z}$ tezą Popkewitza i Lindblad ${ }^{56}$, zjawiska inkluzji i wykluczania stanowią efekt władzy w ramach dyskursów, a polityka równości i włączania ( $w$ tym przypadku przebiegająca pod postacią założonego a priori partnerstwa między rodzicami i nauczycielami) może maskować po-

${ }^{53}$ G. Crozier, J. Davies, Hard to reach parents or hard to reach schools? A discussion of home-school relations, with particular reference to Bangladeshi and Pakistani parents, British Educational Research Journal, 2007, 33, 3.

${ }^{54}$ D. Reay, Tony Blair, the promotion of the "active" educational citizen, and middle-class hegemony, Oxford Review of Education, 2008, 34, 6; D. Reay i in., Re-invigorating democracy?: White middle class identities and comprehensive schooling, Sociological Review, 2008, 56, 2; K. Starego, Sensus communis jako wspólnota równych. Teoretyczne podstawy animacji jako procesu demokratyzacji, Zoon Politikon, 2012, 3.

${ }_{55}$ K. Brien, B.L. Stelmach, Legal and Cultural Contexts of Parent-Teacher Interactions.

56 T.S. Popkewitz, S. Lindblad, Educational Governance and Social Inclusion and Exclusion: Some conceptual difficulties and problematics in policy and research, Discourse: Studies in the Cultural Politics of Education, 2000, 21, 1. 
stępujące wykluczanie na poziomie codziennych konstrukcji i wynikających z nich praktyk. Stelmach i Brian wskazują w swoich badaniach, że w nieoczekiwany sposób rozwiązania legislacyjne dające rodzicom przywilej uczestniczenia w edukacji dzieci, z uwagi na omówioną wyżej zróżnicowaną możliwość realnego korzystania $\mathrm{z}$ tego uprawnienia $\mathrm{w}$ środowisku społecznie defaworyzowanym, prowadzi do wtórnej deprywacji, marginalizacji i osłabienia (disempowerment $)^{57}$. Rozwiązania zarówno prawne, jak i praktyczno-organizacyjne, zorientowane na powiększanie sprawstwa rodziców uczniów w przestrzeni szkolnej i lokalnej, u wielu prowadzą do jego ograniczenia. Ujawniają mechanizmy władzy aktywowane w bezkrytycznym promowaniu uniwersalnej wersji rodzicielskiego zaangażowania, wskazując, że właśnie takie postępowanie dla wielu rodziców może być przytłaczające ${ }^{58}$. Tego rodzaju wiedza ujawnia ukryte na poziomie oczywistości schematy, wzory, mechanizmy, które zamiast działać w imieniu społecznej inkluzji i sprawiedliwości społecznej, w sposób niejawny tworzą podłoże do nowych wykluczeń.

W ramach dyskursu krytyczno-emancypacyjnego wprowadzone zostają zatem do refleksji nad rodzicielskim zaangażowaniem i relacją ze szkołą tematy naznaczone społecznie, dotyczące społecznych nierówności i nowych wykluczeń. Badacze poszukują sposobu wzmacniania pozycji rodzica, zwłaszcza rodzica ze środowisk obcych szkole kulturowej. Poszukują alternatywnych koncepcji współpracy i zaangażowania, tworząc całe aktywności odmienne od katalogów ugruntowanych w wiedzy normatywnej ${ }^{59}$. Domagają się uznania rodziców za kompetentnych partnerów w relacji z nauczycielami, którzy nie tylko doskonale znają swoje dzieci (co jest korzystne w procesie nauczania), ale także mają prawo wypowiadać się na temat swoich dzieci i działania szkoły. Nie chodzi jednak tylko o udzielenie głosu rodzicom, ale o uwzględnienie tego głosu w szerokiej komunikacji szkoły, rodziny i środowiska lokalnego. Uznanie wartości tego głosu jest kluczowe dla budowania dialogu różnych podmiotów wokół dobra dziecka. Dyskurs krytyczno-emancypacyjny ukierunkowany jest na perspektywę różnych rodziców, z różnych warstw społecznych, z różnym etnicznym i kulturowym tłem.

\section{Uwagi końcowe}

Zaprezentowane wyżej przemyślenia i sposób uporządkowania wiedzy na temat rodzicielskiego zaangażowania w edukację dzieci wskazują na potrzebę wzmacniania (zwłaszcza w Polsce) tego nurtu badań, który wiąże się

\footnotetext{
${ }^{57}$ K. Brien, B.L. Stelmach, Legal and Cultural Contexts of Parent-Teacher Interactions.

58 Tamże.

59 Tamże.
} 
z dyskursem krytyczno-emancypacyjnym. Tylko on wprowadza alternatywną do normatywnej narrację na temat rodzicielskiego działania na rzecz edukacji dziecka. Pozwala ona odkrywać inne oblicza współpracy oraz partnerstwa między rodziną i szkołą. Wskazuje na ich społeczne "wytwarzanie” i tym samym generuje pytania o uwarunkowania tego działania. Osadzając proces konstruowania rodzica ucznia i rodzicielskiego zaangażowania w edukację dziecka w szerszym porządku symbolicznym, którego ucieleśnieniem jest między innymi instytucja szkolna, ujawnia obszary przemocy symbolicznej i zarazem daje nadzieję na działania emancypacyjne. Te zaś prowadzą do rozwoju rodzicielskiego zaangażowania, rozumianego jako engagement. Potrzebny w polskiej literaturze przedmiotu dyskurs krytyczno-emancypacyjny daje szanse na pojawienie się $\mathrm{w}$ miejscu prostych i wyświechtanych postulatów „naprawiania” „,biernych" rodziców, krytycznej refleksji nad samymi praktykami szkolnymi i nad porządkiem instytucji oraz na artykulację konieczności ich dogłębnej rewizji w takim kierunku, która pozwoli ujawnić i tym samym uwolnić siłę drzemiącą w każdym rodzicu.

\section{BIBLIOGRAFIA}

Avvisati F., Besbas B., Guyon N., Parental involvement in school: A literature review, Revue d'économie politique, 2010, 120.

Ball S.J., Bowe R., Gewirtz S., School choice, social class and distinction: the realization of social advantage in education, Journal of Education Policy, 1996, 11, 1.

Berg M. Van den, 'Activating' those that 'lag behind': space-time politics in Dutch parenting training for migrants, Patterns of Prejudice, 2016, 50, 1.

Bohn A.P., Sleeter C.E., Multicultural education and the standards movement: A report from the field, Phi Delta Kappan, 2000, 82, 2.

Boonk L., Gijselaers H.J.M., Ritzen H., Brand-Gruwel S., A review of the relationship between parental involvement indicators and academic achievement, Educational Research Review, 2018, 24.

Bourdieu P., Waquant Loic J.D., An Invitation to Reflexive Sociology, Polity Press, Chicago 1992.

Bourdieu P., Passeron J.-C., Reprodukcja. Elementy teorii systemu nauczania, Wydawnictwo Naukowe PWN, Warszawa 2012.

Brien K., Stelmach B.L., Legal and Cultural Contexts of Parent-Teacher Interactions : School Councils in Canada, International Journal about Parents in Education, 2009, 3, 1.

Christopher C.J., Nauczyciel - rodzic. Skuteczne porozumiewanie się, Gdańskie Wydawnictwo Pedagogiczne, Gdańsk 2009.

Crozier G., Parental involvement: Who wants it? International Studies in Sociology of Education, 1999, 9, 3.

Crozier G., Excluded Parents: The deracialisation of parental involvement [1], Race Ethnicity and Education, 2001, 4, 4.

Crozier G., Davies J., Hard to reach parents or hard to reach schools? A discussion of home-school relations, with particular reference to Bangladeshi and Pakistani parents, British Educational Research Journal, 2007, 33, 3. 
Crozier G., Reay D., James D., Making it work for their children: White middle-class parents and working-class schools, International Studies in Sociology of Education, 2011, 21, 3.

Crossing Boundaries: Multi-National Action Research on Family-School Collaboration. Report No. 33., red. D. Davies, V. Johnson, Johns Hopkins University. Center on Families, Communities, Schools, and Children's Learning, Baltimore 1996.

Desforges C., Abouchaar A., The Impact of Parental Involvement, Parental Support and Family Education on Pupil Achievements and Adjustment: A Literature Review with, Education, $2003,30,8$.

Dor A., Israeli teachers' attitudes toward parental involvement in school: A qualitative study, International Journal about Parents in Education, 2013, 7, 1.

Dzierzgowska I., Rodzice w szkole: [poradnik dla dyrektorów szkót, nauczycieli i rodziców], Wydawnictwa CODN, Warszawa 2001.

Epstein J.L., Improving Family and Community Involvement in Secondary Schools DATA, The Education Digest, 2008, February.

Epstein J.L., Dauber S.L., Teacher attitudes and practices of parent involvement in inner-city elementary and middle schools. Report No. 32, [w:] Research On Elementary \& Middle Schools. Report No. 32, 1989.

Epstein J.L., Sheldon S.B., Present and Accounted for: Improving Student Attendance Through Family and Community Involvement, The Journal of Educational Research, 2002, 95, 5.

Eurydice, Rola rodziców w systemach edukacyjnych Unii Europejskiej Informacji o Edukacji, EURYDICE, Bruksela 1997.

Fan X., Chen M., Parental Involvement and Students 'Academic Achievement : A Meta-Analysis, Educational Psychology Review, 2001, 13,1.

Ferlazzo L., Parent Involvement or Parent Engagement, 2009 ttp:/ / www.education.com/reference/article/parent-involvement/.

Goetz M., Chowane pod kloszem, Głos Nauczycielski, 2016, 27-28.

Goodall J., Montgomery C., Parental involvement to parental engagement: a continuum, Educational Review, 2014, 66, 4.

Hawley W.D., Nieto S., Another Inconvenient Truth: Race and Ethnicity Matter, Educational Leadership, 2010, 68, 3.

Hill N.E., Tyson D.F., Parental Involvement in Middle School: A Meta-Analytic Assessment of the Strategies That Promote Achievement, Developmental Psychology, 2009, 45, 3.

Horvat E.M., The Interactive Effects of Race and Class in Educational Research: Theoretical Insights from the Work of Pierre Bourdieu, 2003, 2, 1.

Jankowska A., Rozmowy z rodzicami: Poradnik dla nauczyciela, Wydawnictwo Pedagogiczne, Kielce 2012.

Jeynes W.H., A Meta-Analysis of the Efficacy of Different Types of Parental Involvement Programs for Urban Students, Urban Education, 2012, 47, 4.

Kawula S., Pedagogika społeczna. Dokonania, aktualność, perspektywy. Podręcznik akademicki dla pedagogów, Wydawnictwo Adam Marszałek, Torun 2001.

Kawula S., Brągiel J., Janke A.W., Pedagogika rodziny, Wydawnictwo Adam Marszałek, Toruń 1998.

Kołodziejczyk J., Cieślak H., Analiza wyników ewaluacji zewnętrznych w odniesieniu do wymaganiań. „Rodzice sa partnerami szkoty”, [w:] Ewaluacja w nadzorze pedagogicznym, red. G. Mazurkiewicz, Wydawnictwo Uniwersytetu Jagiellońskiego, Kraków 2011.

Kołodziejczyk J., Walczak B., Kasprzak T., Rodzice - Partnerzy szkoły? Perspektywa ewaluacyjna, Polityka Społeczna, 2012, 1.

Kołodziejczyk J., Walczak B., Rodzice w szkole. Ramy instytucjonalne i charakterystyka zaangażowania, Trzeci Sektor, 2014, 3. 
Konieczna A., Analiza struktury interakcji w sytuacji rozmowy nauczycieli z rodzicami o problemach szkolnych ucznia, Wydawnictwo Akademii Pedagogiki Specjalnej, Warszawa 2009.

Kwaśnica R., Dyskurs edukacyjny po inwazji rozumu instrumentalnego. O potrzebie refleksyjności, Dolnośląska Szkoła Wyższa, Wrocław 2014.

Lareau A., Horvat E.M., Moments of Social Inclusion and Exclusion Race, Class, and Cultural Capital in Family-School Relationships, Sociology of Education, 1999, 72, 1.

Lulek B., Rodzice jako liderzy w edukacji szkolnej wtasnego dziecka. O trudnościach w budowaniu rodzicelskich zespotów w szkole, [w:] Education and upbringing in the educational school system, red. K. Denek, A. Kamińska, P. Oleśniewicz, seria „Edukacja Jutra”, Oficyna Wydawnicza Humanitas, Sosnowiec 2013.

Lulek B., Wspótpraca szkoły, rodziny i środowiska, Wydawnictwo Uniwersytetu Rzeszowskiego, Rzeszów 2008.

Łobocki M., O wspótpracy nauczycieli i rodziców w rozumieniu tradycyjnym, [w:] Nauczyciele i rodzice, red. I. Nowosad, M.J. Szymański, Oficyna Wydawnicza UZ -AP, Zielona Góra - Kraków 2004.

Łobocki M., Współdziałanie nauczycieli i rodziców w procesie wyychowania, Nasza Księgarnia, Warszawa 1985.

Łukasik J., Jagielska K., Solecki R., Nauczyciel. Wychowawca. Pedagog. Szkolne wyzwania, Wydawnictwo Jedność, Kielce 2013.

Markow D., Pieters A., The MetLife Survey of The American Teacher: Teachers, Parents and the Economy, MetLife Inc, New York 2012.

Mendel M., Partnerstwo rodziny szkoły i gminy, Wydawnictwo Adam Marszałek, Torun 2000.

Mendel M., Aktywna szkoła - bierni rodzice: anomia, mit czy przemieszczenie znaczeń? [w:] Pedagogika rodziny na progu XXI wieku, red. A.W. Janke, Wydawnictwo Edukacyjne Akapit, Toruń 2004.

Mendel M., Miejsca rodziców w przestrzeni szkoły [w:] Nauczyciele i rodzice, red. I. Nowosad, M.J. Szymański Oficyna Wydawnicza UZ - AP, Zielona Góra - Kraków 2004.

Mendel M., Rodzice i nauczyciele jako sprzymierzeńcy, Wydawnictwo Harmonia, Gdańsk 2007.

Mendel M., Pedagogika miejsca wspólnego. Miato i szkoła, Wydawnictwo Naukowe Katedra, Gdańsk 2018.

Murray K.W. i in., Barriers and Facilitators to School-Based Parent Involvement for Parents of Urban Public Middle School Students, SAge Open, 2014, 4, 4.

Nauczyciele i rodzice : komunikacja, relacje, wspótpraca, red. J. Łukasiewicz-Wieleba, Wydawnictwo Akademii Pedagogiki Specjalnej im. Marii Grzegorzewskiej, Warszawa 2014.

Nowosad I., W poszukiwaniu warunków wspótpracy nauczycieli i rodziców, [w:] Nauczyciele i rodzice, red. I. Nowosad, M.J. Szymański, Oficyna Wydawnicza UZ -AP, Zielona Góra - Kraków 2004.

OECD, The Well-being of Nations. The Role of Human and Social Capital, OECD, Paris 2001.

Olubiński A., Wspótpraca rodziny i szkoty jako funkcja życia społecznego, [w:] Wspótprzestrzenie edukacji, red. M. Nyczaj-Drąg, M. Głażewski, Oficyna Wydawnicza Impuls, Kraków 2005.

Patacchini E., Patacchini E., Zenou Y., Intergenerational Education Transmission: Neighborhood Quality and/or Parents' Involvement? Institute for Study of Labor, Working PaperIZA DP No. 2508. Stokholm 2007.

Pietruszka L., Rodzina i szkoła: O wspótpracy nauczycieli-wychowawców z rodzicami w procesie edukacji wczesnoszkolnej, Wydawnictwo KUL, Lublin 2017. 
Polak K., Integracja rodziców i nauczycieli jako przykład edukacyjnej iluzji, [w:] Sprawcy i/lub ofiary dziatań pozornych w edukacji szkolnej, red. M. Dudzikowa, K. Knasiecka-Falbierska, Oficyna Wydawnicza Impuls, Kraków 2013.

Popkewitz T.S., Lindblad S., Educational Governance and Social Inclusion and Exclusion: Some conceptual difficulties and problematics in policy and research, Discourse: Studies in the Cultural Politics of Education, 2000, 21, 1.

Posey-Maddox L., Professionalizing the PTO: Race, Class, and Shifting Norms of Parental Engagement in a City Public School, American Journal of Education, 2013, 119, 2.

Posey-Maddox L., Haley-Lock A., One Size Does Not Fit All: Understanding Parent Engagement in the Contexts of Work, Family, and Public Schooling, Urban Education, 2016.

Reay D., Unequal Childhoods: Class, Race and Family Life by Annette Lareau:Unequal Childhoods: Class, Race and Family Life, 2003, 1989.

Reay D., Tony Blair, the promotion of the "active" educational citizen, and middle-class hegemony, Oxford Review of Education, 2008, 34, 6.

Reay D., Ball S.J., 'Making their Minds Up': family dynamics of school choice, British Educational Research Journal, 1998, 24, 4.

Reay D. i in., Re-invigorating democracy?: White middle class identities and comprehensive schooling, Sociological Review, 2008, 56, 2.

Segiet W., Psychospołeczna charakterystyka stosunków rodzice-nauczyciele, [w:] Nauczyciele i rodzice, red. I. Nowosad, M.J. Szymański, Oficyna Wydawnicza UZ -AP, Zielona Góra - Kraków 2004.

Segiet W., O zwiazku edukacji z rodzina: Społeczne konteksty i jednostkowe biografie, Wydawnictwo Naukowe UAM, Poznań 2013.

Sleeter C.E., Soriano-Ayala E., González-Jimenez A.J., Community Funds of Knowledge and Immigrant Associations: An Exploration from Southern Spain, [w:] Roma inclusion - International and Greek experiences, red. S. Mitakidou, Copy City, Thessaloniki 2015.

Starego K., Sensus communis jako wspólnota równych. Teoretyczne podstawy animacji jako procesu demokratyzacji, Zoon Politikon, 2012, 3.

Symeou L., Family/school liaisons in Cyprus: an investigation of families' perspectives and needs, [w:] Building Bridges Between Home and School, red. F. Smit, H. Moerel, K. Van Der Wolf, P. Sleegers, ITS/SCO - Kohnstamm Instituut, Nijmegen - Amsterdam 2001.

Szymański M.J., Rodzina i szkoła w procesie gwattownej zmiany społecznej, [w:] Nauczyciele i rodzice, red. I. Nowosad, M.J. Szymański, Oficyna Wydawnicza UZ -AP, Zielona Góra - Kraków 2004.

Szymański M.J., Rodzina i szkoła - wspólnota dążeń czy interesów? [w:] Rodzina i szkoła: od rozpoznania problemów do efektywnej wspótpracy, red. M. Jaśko, J. Siewiora, Wydawnictwo Diecezji Tarnowskiej Biblos, Tarnów 2017.

Śliwerski B., Uspołecznienie szkoły, Edukacja i Dialog, 1995, styczeń.

Śliwerski B., Możliwości rozpoznawania sensu wspótdziatania szkoty, rodziców i uczniów w społeczeństwie wolnorynkowym, [w:] Nauczyciele i rodzice, red. I. Nowosad, M.J. Szymański, Oficyna Wydawnicza UZ -AP, Zielona Góra - Kraków 2004.

Śliwerski B., Klinika szkolnej demokracji, Oficyna Wydawnicza Impuls, Kraków 2008.

Śliwerski B., Meblowanie szkolnej demokracji, t. 2, Wolters Kluwer Polska, Warszawa 2017.

Theodorou E., Reading between the lines : exploring the assumptions and implications of parental involvement, International Journal about Parents in Education, 2007, 1.

Vincent C., Martin J., Class, Culture and Agency : researching parental voice, Discourse : Studies in the Cultural Politics of Education, 2002, 23, 1. 
Vincent C., Rollock N., Ball S.J., Gillborn D., Being strategic, being watchful, being determined: Black middle-class parents and schooling., British Journal of Sociology of Education, 2012, $33,3$.

Walker J.M.T., Hoover-Dempsey K. V, Whetsel D., Green C.L., Parental Involvement in Homework. A Review of Current Research and Its Implications for Teachers, After School Program Staff, and Parent Leaders, Harvard Family Research Project, Harvard Graduate School of Education, Cambridge 2004.

Walker J.M.T. i in., Parental Involvement: Model Revision through Scale Development, The Elementary School Journal, 2005, 106, 2.

Watson G.L., Sanders-Lawson R.E., McNeal L., Understanding Parental Involvement in American Public Education Department of Leadership, International Journal of Humanities and Social Science, [Special Issue - October], 2012, 2, 19.

Whalley M., Jak włączyć rodziców do nauki dzieci, Wydawnictwa Szkolne i Pedagogiczne, Wydawnictwa Fraszka Edukacyjna, Warszawa 2008.

Whitaker M., Hoover-Dempsey K.V, School Influences on Parents' Role Beliefs, The Elementary School Journal, 2013, 114, 1.

Winiarski M., Rodzina, szkoła, środowisko lokalne: problemy edukacji środowiskowej, Instytut Badań Edukacyjnych, Warszawa 2000. 